\title{
Industrial Revolution 4.0: Prophetic Character Education in Purpose to Become the Ideal Society of Indonesia
}

\author{
Dimas Aldi Pangestu ${ }^{1}$, Ajat Sudrajat ${ }^{2}$ \\ Program Pascasarjana Pendidikan Sejarah Universitas Negeri Yogyakarta, Yogyakarta Indonesia \\ 11dimasaldi.2019@student.uny.ac.id, 2ajat@uny.ac.id
}

\begin{abstract}
The purpose of this paper is to determine the usefulness of prophetic character education in creating an ideal society for the industrial revolution era 4.0.The method used in this article is descriptive analytic where the data collection techniques used are derived from literature review and analyzed using interactive analysis.The social problemsare damage for young generations due to internet effects. The solution this problem is through the prophetic character education. The prophetic character education derived from the exemplary of Prophet Mohammad as a figure who can be seen as a role model.The prophetic character education itself consists of four terms and three principles. The four terms are community, vision, dinamic movement, and leadership. The three principles are trancendence, humanity, and liberation. The problems that exists in the industry 4.0 is expected to be solved by this prophetic character education in order to create an ideal society.
\end{abstract}

Keywords: Prophetic Character Education, Ideal Society, and Industrial Revolution 4.0.

\section{Introduction}

Schwab [1] stated that the industry 4.0 can fundamentally change how the people live and work that integrates the physical, digital, and biological world. The big leap has occurred in the industry 4.0. Fundamentally, the industry 4.0 will causing a change in the way of how human think, live, and to interact one with another. Renald Kasali [2] even express his opinion that the era of industry 4.0 would disrupts various human activities in various fields. The era of industry 4.0 should be wise and carefully addressed by the subjects of industry, and the government as an administrator should prepare the fair quality of human resources.

Furthermore, the industry 4.0 era as an era of the internet of things tend to cause a social harm. Technological development is followed by moral decadence which is truly at an alarming level [3]. According to Myers [4], the disadvantage social impacts of the internet are the deindividuation, time diversion from face to face relationship and slactivism. What Meyrs had stated has becoming real events in the Indonesia's social life recently.

Deindividualization takes form in sexual exploitation, hate speech, piracy, and cyber bullying. Time diversion from face to face relationship causing the decline in social interaction [5]. The social media then becoming a wet soil for the irresponsible users to spread hoax and hate speech. This will leads into slactivism or the polarization of groups that contributes in dividing the Nation. The recent polarization in Indonesia has not only based on political choice, but also primordial identity [6].

The human resources in the Industry 4.0 holds a strategic role in order to achieving the target of Making Indonesia 4.0, contradict with the given social condition of the Nation. Even 
more, the Industry 4.0 demands human resources who excel in adapting to the environment and be able to see the new potential that can be developed. The potential of the Industry 4.0 needs to be utilized for the sake of the Nation's development. Especially that Indonesia will achieve the demography bonus.

The potency of demography bonus that posessed by Indonesia becoming an important issue to address. The decline in fertility gives a probability towards the escalation of the wellbeing. The productive potential would be larger than the non-productive one [7]. This potency could be Indonesia's chance to have more enhancement in the productivity.

A well preparation is needed to develop the human ability to optimalize the potency of human resources. Human resources need to have noble character and character must be built through education [8]. The preparation itself - among the other method - can be implemented through education. The optimalization of the demographic bonus potencies can define the development of a Nation. The issue about the development of the human resources is the current important issue to deal with. Following the current issue, President Joko Widodo initiate a concept known as "revolusi mental" (mental revolution). Mental revolution can potentially to develop people because Indonesia is country based on religion becoming foundation to ideal society.

As a country with the largest Muslim population, Indonesia has the potential to achieve a civilized ideal society. The other potential is that the laws that based on the Quran and the Hadith is well established by the constitution or by the regional constitution with shariah principles. Indonesia's role in the eyes of the world is very active in promoting world peace. The only thing remains to do is to reinforce monotheism and character-building [9].

The establishment of ideal society such as those in Madina requires social construction, especially in the character field. Prophetic character education is based on the prophetic qualities of which the Prophet Muhammad had successfully taught his companions both the teachings and the exemplars that enabled His companions to perform with great monotheism and high morals [10].

It is suggested to make a certain solution to solve the potencies and issues that has been discussed beforehand. The purpose of this paper is to determine the usefulness of prophetic character education in creating an ideal society for the industrial revolution era 4.0. A founding is needed to develop the character of Indonesian people so that they can minimalize the negative impact from the internet and rebuild the unity (Bhineka) that currently is in a grave danger. One of the solution is by implementing the prophetic character education. The prophetic character education will develop the human resources since an early age in order to build an ideal society where they can create a harmony in life and bring Indonesia to its advanced state.

\section{Research Method}

This paper is using descriptive analytic method. According to Damadi [11] descriptive method is a procedure of problem-solving by describing situation object/subject research based on evidence that appears or scratch. The analytical method is used to analyze various problems to assist the dynamic theme of research [12]. Descriptive analytic method is a procedural problem solve by describing subject/object research to analyze various problems to assist the dynamic theme of research based on evidence that appears or scratch. The flow of 
writing this paper is problem identification, data collection and literature, data analysis, and writing paper.

Data collection techniques carried out through study literature.Relevant literature sources are processed into a descriptive analysis of data that results in conclusions and suggestions. In writing this paper, the author uses an interactive analysis model deal with that proposed by Miles and Haberman. The interactive analysis is covering four components namely data collection, data reduction, display, and verification of data or conclusion drawing [13].

\section{Results and Discussion}

Indonesia is highly profitable with a potential demographic bonus to come in 2030. This potential is a great benefit for Indonesia where it can potentially become a developed nation. But the utilization of the demographic bonus opportunities has not been optimized yet. The government is not as strong in building human resources, for example like in the education sector [14]. Meanwhile, the assets from human resources on demographic bonuses need to be optimized and avoided from negative things, especially in today's challenging industrial revolution 4.0.

The problem-solving phase due to the internet-based industrial revolution 4.0 has brought a tremendous impact on the next generation. Preparing with education towards the next generation can lead either to successfulor failed potential in utilizing the demographic bonuses. One of the steps in making the demographic bonus successful is by avoiding the Indonesian from the negative effects and negative mindset through the prophetic character education developing from concept Islam as Science.

Islam as Science has four ethical paradigms of Islam. First, regarding the end goal of the Islamic paradigm is how close the human beings are to the Almighty, Islam demands a transformation into transcendence. Second, the involvement of the people who have to fight in human history involves three pillars of humanization (humanity), liberation (liberation of humanity from oppression) and transcendence (devouting humanity's faith towardsthe God). Third, methodological objectivism in which a Muslim researcher should be objective at researching both Muslim and non-Muslim objects. Fourth, Islam as Science will always be critical towards all sciences, secular or not, even to itself [15].

The prophetic character education are based on three pillars of humanization, liberation and transcendence. The three pillars are sourced in the Al-Imran verse 110. It is an educational process that encompasses its. The three pillars of humanization, liberation, and transcendence are the benchmarks of social change. Humanization as a derivation of Amar ma'ruf contains the meaning of humanity. Liberation is a derivation from the term nahi munkar contains the meaning of liberation. Transcendence is a dimension of the human faith. These three pillars have profound implications to frame a more humanistic survival of the mankind [16].

The three pillars of prophetic education are simultaneously done both individually and collectively. The implementation of all three is expected to be integrative and holistic. Prophetic education will help in the process of implementing the education system including all the necessary elements of the learner's life. It will form an education that has strong bargaining power in society [17].

The prophetic character education is a transferring process of character that is based on the Prophet Muhammad's behavior. Exemplary behavior encompasses all aspects of his words, actions, and decisions. Prophet Muhammad is an exemplary figure for mankind according to 
the word of Allah the Almighty in the letter of Al-Ahzab verse 21 [18].The sources of the Prophet Muhammad's exemplary behavior have four main components in the prophetic character education which are honesty, professional, communicative and intelligent. These four prophecies serve as guidelines for honesty and conscientiousness, for being trustworthy and committed, for communicating skills and for being a problem solver [19].

The teaching of the prophetic character which derived from the four exemplary components of Prophet Muhammad has created an ideal society. The character building which rooted towards the transcendental structures can briefly transform the jahiliyah Arab community into civilized society. The characters built by the Prophet Muhammad has turned the Arab civilization into a civilized and ideal civilization that has an egalitarian nature, acknowledge the equality of rights and obligations, equality in general, mutual respect and fairness, and prosperity.

The prophetic character education in its implementation is based on four conditions and three pillars. The four basic requirements are community, vision or purpose, dynamic movement, and leadership. For the community and the leaders who become the executor of the vision and program must implement the three pillars at once: transcendence, humanization, and liberation [20].

The social community plays a role in the character education. Humans usually spent more time outdoors. Social communities of people is form and develop each child's character. Prophetic character education encourages people to continue learning throughout their lives, without being bound by age, values, and culture. Humans can learn how to become an example for others, as long as he learns the three pillars of transcendence, humanization, and liberation.

The vision and purpose of the prophetic character education in the industrial revolution 4.0 is to build a dignitious character. The construction of this character aims to create a highquality human resources with moral values. High-quality, well-mannered human resources, and has the contextualized transcendence, humanization and liberation can establish the ideal society. An ideal society is expected to optimize the potential for demographic bonuses and may fulfill Indonesia's ambitions to become a developed country.

The dynamic movement of prophetic character education can be incorporated into the school's implementation model. The school develop the implementation model into three forms: integration into subjects, school civilization and extracurricular [21]. The cultivation of a prophetic character through the integration of the subject does not depend solely on religious subjects but also embedded in other subjects. The prophetic character education can also be inserted into the reflection sections from each lesson.

School civilization with the prophetic character can be done by providing the teachers with exemplary interventions. The intervention can be done through the rules made according to the Quran and the Hadith in which the schoolmen are agree to implement. The concept of exemplarythen modeled through the ideal teachers.

Ideal teachers as a role model has exceed its definition in the professionalism. As an ideal teachers they are emphasized to become more professional, self-motivated, self-discipline, sincerity, purity of birth and inner self, forgiveness, patience, self-evaluation, self-awareness, self-development, self-learners, effective relationships, high empathy, and obey the code of conduct. InIndonesia, the teacher's code of conduct is referred to the final issue of 2006 PGRI Central Conference [22].

Extracurricular activities are included in one of the models that can be developed in the integration of prophetic character education. Extracurricular activities are considered holistic activities in education. Extracurricular activities can include cognitive, affective and 
psychomotor [23]. Through the extracurricular activities, the learners can receive the guidance on their prophetic character as well as its application. Through extracurricular activities, the students can reflect on their existing professional values and apply them to their peers.

Leadership become an role that is able to internalize prophetic education. Prophetic leadership is needed to internalize the prophetic character education. Prophetic leadership is the ability of one person to influence others in achieving the goal like the one that has been done by Prophet Muhammad. Prophetic leadership itself has several types of leadership [24].

The types of prophetic leadership are authoritarian, laissez-faire and democratic. Authoritarian leadership in prophetic leadership is a firm stance in giving judgment and execute of the law of Allah Almighty. Furthermore, laissez-faire leadership that promotes an unselfish attitude toward others, always shows the good and the bad of an act. In this type of leadership, the attitude that seems to be promoted is responsibility. The following democratic leadership type is shown by the leaders who involve their subordinates in making decisions, delegating authority and using feedback to maintain their subordinates [25].

The ethics in building the paradigm of prophetic character in the industry 4.0 era is based on Islamic ethics as Science, likestated by Kuntowijoyo [26] that the end goals of the Islamic paradigm are the involvement of the people in history, methodological objectivism, and the attitude of the Islamic paradigm. Islam requires transcendence in its transformative purpose. During the transformation, the humanity struggled to humanizing people, liberate mankind from oppression, and bring humanity to God.

The ultimate goal of prophetic character education is to create an ideal society. The ideal society was exemplified by the Medina society of the Prophet Muhammad era. The ideal society in Medina upholds the values of culture and civilization, with no rights of nonMuslims being hindered or betrayed, applying the principles of social justice, and equality [27]. The achievement of this end goal requires the involvement of the people in the process.

The involvement of the people in achieving the ultimate goal is important in building the prophetic character education aspects. The process of humanizing people, freeing people from oppression, and bringing people to faith in God is the stage of the process to achieve the ultimate goal of an ideal society.

Humanizing people with education is the most appropriate way to go. Through prophetic character education, which based on Islamic values that has the essence of humanism. Islam makes the dimension of humanity as the orientation of its education. This process then makes humans who have intellect, emotional abilities and spiritual abilities [28].

After Having an intellectual, emotional and spiritual ability, they could generate a prosocial attitude. According to Myer in Muryadi and Matulessy [29], the pro-social attitude arises from the existence of religious power. The power of religion is a powerful factor in shaping a helpful spirit, to protect and secure a person to find his or her existence. Religion helps one to be tolerant, cooperative, honest, disciplined, passionate, respectful of the rights and well-being of others, optimistic and helpful.

Objectively researching the prophetic character without any lies and loss of self is needed to achieve good results. The results of this study are useful to both the human self and the ideal community environment. The attempt to reorient religious understanding both individually and collectively in understanding and responding to the realities of the age with the divine perspective is ongoing and critical. Critical attitudes can lead to reorientation efforts in every development of the paradigm. 


\section{Conclusion}

The teaching of the prophetic character was born from the concept of Islam as the science like has been stated by Kuntowijoyo. Islam as Science is a demystification movement from text to context, which has epistemology in the form of transcendental structuralism. The prophetic character education is developing from Islam as Science.It comes from the four components of the attributes of the Prophet Muhammad that have created an ideal society. Prophetic character education in its implementation is based on four conditions and three pillars. Four conditions are basic, namely community, vision or goals, dynamic motion, and leadership. For communities and leaders who are implementing the vision and program must absorb three pillars at once, namely transcendence, humanization, and liberation. The vision and purpose of prophetic character education in the face of the industrial revolution 4.0 is to foster noble character. This character building aims to create quality human resources and noble character. Quality human resources and noble character and have contextualization transcendence, humanization, and liberation can create the realization of an ideal society. Cultivating schools with prophetic characters can be done by providing intervention and examples from the teachers. The intervention was carried out through regulations made based on the Al-Qur'an and Hadist that were agreed upon by the school community to be implemented.

\section{Acknowledgements}

We would like thank addressed to the Indonesia Endowment Fund for Education (LPDP) for the kind support his the study.

\section{References}

[1] Schwab, Klaus. The Fourth Industrial Revolution. Geneva: World Economic Forum. pp. 12. (2016).

[2] Kasali, Rhenald. Disruption. Jakarta: Kompas. (2017).

[3] Iskarim, Mochamad. Dekadensi Moral di Kalangan Pelajar (Revitalisasi Strategi PAI dalam Menumbuhkan Moralitas Generasi Bangsa). Edukasia Islamika. Vol. 1, No.1, pp. 2. (2016).

[4] Myers, David G. A Social Psychology of the Internet. International Forum of Teaching and Studies, Vol. 12, No. 1, pp. 4. (2016).

[5] Hakim, Siti Nurina., \& Raj, Alifatullah Alyu. Dampak Kecanduan Internet (internet addiction) pada Remaja. Prosiding Temu Ilmiah X Ikatan Psikologi Perkembangan Indonesia. Semarang: Ikatan Psikologi Perkembangan Indonesia. pp. 281. (2017).

[6] Triguna, I.B.G Yudha. Kebhinekaan Bangsa Indonesia: Urgensi dan Relevansinya dalam Era Revolusi Industri 4.0. Dharmasmrti Jurnal Imu Agama \& Kebudayaan. Vol. 10, No. 2, pp. 47. (2019).

[7] Konadi, Win.,\& Iba, Zainuddin. Bonus Demografi Modal Membangun Bangsa yang Sehat dan Bermartabat. Variasi Majalah Ilmiah Universitas Almuslim. Vol. 2, No.6, pp. 19. (2011).

[8] Musrifah. Pendidikan Karakter dalam Persfektif Islam. Edukasia Islamika. Vol. 1, No. 1, pp. 120, (2016). 
[9] Fazillah, Nur. Konsep Civil Society Nurcholish Majid dan Relevansinya dengan Kondisi Masyarakat Indonesia Kontemporer. Al-Lubb:International Journal of Islamic Thoughgt and Muslim Cultural. Vol. 2, No. 1, pp. 134, 212. (2017).

[10] Roqib, Moh. Pendidikan Karakter. Vol. 3, No. 3, pp. 242, 248, (2013).

[11] Damadi, Hamid. Metode Penelitian Pendidikan. Bandung: Alfabeta. pp. 7 (2011).

[12] Mukani. Dinamika Pendidikan Islam. Malang: Madani. pp. 117. (2016)

[13] Sugiyono. Metode Penelitian Pendidikan. Bandung: Alfabeta. pp. 438-439. (2019).

[14] Jati, Warsisto Raharjo. Bonus Demografi Sebagai Mesin Pertumbuhan Ekonomi: Jendela Peluang Atau Jendela Bencana di Indonesia. Populasi. Vol. 26, No. 1, pp. 38. (2015).

[15] Kuntowijoyo. Muslim Tanpa Masjid. Bantul: IRCiSoD. pp. 82. (2018).

[16] Rosyadi, Khoiron. Pendidikan Profetik. Yogyakarta: Pustaka Pelajar. pp. 304 (2004).

[17] Roqib, Moh. Prophetic Education Kontekstualisasi Filsafat dan Budaya Profetik dalam Pendidikan. Purwokerto: STAIN Press. pp. 47, 296-297, 152, 156. (2011).

[18] Ningsi, Eka Fitria., \& Zuliana, Erni. Nilai-nilai Karakter Profetik pada Pembelajaran Matematika Pokok Bahasan Aljabar. Prosiding International Seminar The Dynamics of Malay Islamic World in Responding to Contemporary Global Issues. Palembang: UIN Raden Fatah. pp. 174. (2016).

[19] Roqib, Moh. Prophetic Education Kontekstualisasi Filsafat dan Budaya Profetik dalam Pendidikan. Purwokerto: STAIN Press. pp. 47, 296-297, 152, 156. (2011).

[20] Roqib, Moh. Prophetic Education Kontekstualisasi Filsafat dan Budaya Profetik dalam Pendidikan. Purwokerto: STAIN Press. pp. 47, 296-297, 152, 156. (2011).

[21] Wati, Dian Chrisna., \& Arif, Dikdik Baehaqi. Penanaman Nilai-nilai Religius di Sekolah dasar untuk Penguatan Jiwa Profetik Siswa. Prosiding Konferensi Nasional Kewarganegaraan III. Yogyakarta: Universitas Ahmad Dahlan. pp. 61. (2017).

[22] Danim, Sudarwan. Pengembangan Profesi Guru: dari Pra-Jabatan, Induksi, ke ProfesionalanMadani. Jakarta: Penerbit Kencana Prenada Media Group. pp. 259. (2012).

[23] Jalil, Jasman. Pendidikan Karakter: Implementasi oleh Guru, Kurikulum, Pemerintah dan Sumber Daya Pendidikan. Sukabumi: Jejak Publisher. pp. 130. (2018).

[24] Anwar, Ahmad. Tipe Kepemimpinan Profetik Konsep dan Implementasi dalam Kepemimpinan di Perpustakaan. Pustakaloka Jurnal Kajian Informasi dan Perpustakaan. Vol. 9, No. 1, pp. 74, 75. (2017).

[25] Anwar, Ahmad. Tipe Kepemimpinan Profetik Konsep dan Implementasi dalam Kepemimpinan di Perpustakaan. Pustakaloka Jurnal Kajian Informasi dan Perpustakaan. Vol. 9, No. 1, pp. 74, 75. (2017).

[26] Kuntowijoyo. Islam sebagai Ilmu. Yogyakarta: Tiara Wacana. pp. 81. (2006)

[27] Ali, Ummu Salamah. Peradaban Islam Madinah (Refleksi terhadap Promordialisme Suku Auz dan Kharaj). Kalimah Jurnal Studi Agama dan Pemikiran Islam. Vol. 15, No. 2, pp.201. (2017).

[28] Idris, Saifullah., \& Tabrani ZA. Realitas Pendidikan Humanime dalam Konteks Pendidikan Islam. Jurnal Edukasi Media Kajian Bimbingan Konseling. Vol. 3, No. 1, pp. 98, 99. (2017).

[29] Muryadi \& Matulessy, Andik. Religiusitas, Kecerdasan Emosi dan Perilaku Prososial Guru. Jurnal Psikologi Tabularasa. Vol. 7, No. 2, pp. 545. (2012). 